\title{
Specialized International Equity Investment With Forward Foreign Exchange Trading: A U. S. Viewpoint
}

Marlena Akhbari, (E-mail: Marlena.akhbari@wright.edu), Wright State University Nicolas Gressis, (E-mail: Nicolas.gressis@ wright.edu), Wright State University

Fall Ainina, (E-mail: Fall.ainina@wright.edu), Wright State University

\begin{abstract}
Assuming risk-neutrality and the random walk model we derive a rule-of-thumb that periodically selects the appropriate foreign stock index and is either long or short foreign currency contracts. The empirical results of testing the rule-of-thumb with an investment universe of six major foreign equity markets show that our rule-of-thumb provides performance superior to investing in foreign stock indices alone. In addition, we test and reject the Unbiased Forward Rate Hypothesis (UFRH) in favor of the Random Walk Hypothesis (RWH).
\end{abstract}

\section{INTRODUCTION}

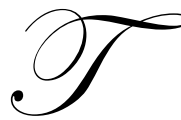

he benefits of international diversification have long been recognized. A recent ex ante international portfolio selection study by Eun and Resnick (1994) shows that when portfolios of stocks, bonds, and stocks and bonds are considered and the investment also includes forward contracts, the risk/return configuration is much better over those without forward contracts for international portfolios of bonds and stocks and bonds, but only minimal improvement is obtained for stock portfolios. A more recent study by Eun and Resnick (1997) explores passive and active strategies for handling exchange rate risk. Using the random walk model they consider three conditional hedging strategies. One of particular interest to us involves selling currency forward when it is trading at a premium but buying currency forward when it is trading at a discount. Their empirical results indicate that the random walk strategies exhibit superior performance in comparison to the unhedged and passive hedging strategies under all parameter estimation techniques. Eun and Resnick (1997, p.40) state: "These results imply that the random walk model provides a good estimate of next period's spot rate of exchange." ${ }^{1}$

In these and other studies, the position taken in forward contracts is determined only after the international investments are selected. Grinold and Meese (2000, p. 58) state, for example, that "It is common practice to ignore hedging in determining the fraction of assets to be invested internationally and then ask whether those assets should be hedged." Our results suggest a revision to this common practice.

It should be noted that international diversification of securities portfolios does not imply reduction or elimination of foreign exchange risk. As Eaker and Grant (1990) and Eun and Resnick (1997) point out, portfolio managers may enhance the risk/return performance of their portfolios by taking advantage of foreign currency returns.

The use of technical trading rules to earn abnormal returns in the foreign exchange market has been explored by several authors. Works by Surajaras and Sweeney (1992), Levich and Thomas (1993), Neely (1997), and LeBaron (1999) all suggest that technical trading rules may provide annual abnormal returns between $3 \%$ and $10 \%$ after adjusting for transactions costs. More recently, authors have explored the notion that this outperformance may have been short-lived and abnormal profits may be eroding as more market participants take advantage of this apparent inefficiency. For example, Lee and Mathur (1996), Cheung and Wong (1997) and Lee et al (2001) find that technical trading rules do not generate abnormal profits in later periods of study. 
The trading rules examined by these authors vary from relatively simple moving averages to more complex rules selected by genetic algorithms. The results verify that the more complicated rules outperform the simple ones.

Froot and Thaler (1990) examine whether various risk premia might account for the apparent bias in forward rates as examined by several authors. ${ }^{2}$ They conclude that "there is no positive evidence that the forward discount's bias is due to risk...." but rather that there "is positive evidence which suggests ... that the bias is attributable to expectational errors and not risk." (Froot and Thaler, p. 190). They suggest that explanations which allow for the possibility of market inefficiency should be seriously considered.

This paper examines the benefits of concentrating on foreign currency returns. Based on quarterly data over the period 1974-1996, we consider two strategies: a) selectively selling forward contracts when the forward rate is at a premium and selectively buying forward contracts when the forward rate is at a discount, and b) leaving foreign exchange exposure unhedged. It should be noted that our strategy is consistent with "hedging" and "speculating" on exchange risk only if the terms are loosely defined to represent foreign exchange contracts sold and bought. Since our investor is risk-neutral, $\mathrm{s}(\mathrm{he})$ has no interest in risk reduction. Therefore, we dispense with the use of efficient frontiers and concentrate on individual foreign equity markets that maximize expected utility which is equivalent to maximizing expected portfolio return, under the assumption of risk neutrality.

We find that risk neutrality, along with the Random Walk Hypothesis, produces a rule-of-thumb whose sequential application obtains performance results that are much better than those produced with a strategy based on the Unbiased Forward Rate Hypothesis. Unlike many of the trading rules employed in previous studies that depend on patterns in spot exchange rates for their formulation, we use a simple trading rule based on the relative values of forward and spot rates.

The rest of the paper is organized as follows. The formulas for the return without forward contracts, the return with forward contract purchases, and the return with forward contract sales are presented in Section 2. These formulas provide the rule-of-thumb to be used by the risk-neutral investor in the selection of a foreign stock market. The data and the analytical framework are described in Section 3. Section 4 contains a discussion of the results of strategies based on the Unbiased Forward Rate Hypothesis (UFRH) and on the Random Walk Hypothesis (RWH). Concluding comments are offered in Section 5. Finally, recommendations for future research are included in Section 6.

\section{FORMULAS FOR FOREIGN EQUITY RETURNS, WITH AND WITHOUT FORWARD CONTRACTS}

\section{Expected Return Formulas under the Unbiased Forward Rate Hypothesis (UFRH) and the Random Walk Hypothesis (RWH)}

To an international investor, foreign exchange risk may substantially contribute to the overall portfolio risk; it may also provide an opportunity to earn abnormal returns. Our risk-neutral investor is, of course, interested in the latter.

Assume that the U.S. investor employs a strategy based on the UFRH. This assumption implies that

$\mathrm{F}_{0}=\mathrm{S}_{1}^{*}$

where $\mathrm{F}_{0}=$ the current forward exchange rate in $\$ / F x$,

$\mathrm{S}_{1}=$ future spot rate of Fx, in $\$ / F x$, and

*denotes expected value

For illustrative purposes, let the German stock market represent the foreign equity market. Appendix A shows the expected portfolio return is given as 


$$
\left(1+\mathrm{R}_{\mathrm{P}}^{\$}\right)^{*}=\left(\left(1+\mathrm{R}_{\mathrm{S}}^{\mathrm{DM}}\right) \frac{\mathrm{S}_{1}}{\mathrm{~S}_{0}}\right)^{*} \pm \mathrm{k}\left(\frac{\mathrm{S}_{1}^{*}-\mathrm{F}_{0}}{\mathrm{~S}_{0}}\right)
$$

where $\mathrm{R}_{\mathrm{P}}^{\$}=$ portfolio rate of return from the U.S. investor's viewpoint,

$\mathrm{R}_{\mathrm{S}}^{\mathrm{DM}}=$ the rate of return in DMs on the German stock index, and

$\mathrm{S}_{0}\left(\mathrm{~S}_{1}\right)=$ current (future) spot rate of DM, in \$/DM.

Under the UFRH, equation (2) simplifies to

$$
\left(1+\mathrm{R}_{\mathrm{P}}^{\$}\right)^{*}=\left(\left(1+\mathrm{R}_{\mathrm{S}}^{\mathrm{DM}}\right) \frac{\mathrm{S}_{1}}{\mathrm{~S}_{0}}\right)^{*} \pm \mathrm{k}\left(\frac{\mathrm{F}_{0}-\mathrm{F}_{0}}{\mathrm{~S}_{0}}\right)
$$

or

$$
\left(1+\mathrm{R}_{\mathrm{P}}^{\$}\right)^{*}=\left(\left(1+\mathrm{R}_{\mathrm{S}}^{\mathrm{DM}}\right) \frac{\mathrm{S}_{1}}{\mathrm{~S}_{0}}\right)^{*}
$$

The above expression suggests that under the UFRH, the expected performance of an investment in a foreign equity market without forward contracts will be statistically similar to that of the same foreign equity market with forward contracts.

On the other hand, if the U.S. investor employs a strategy based on the RWH, then

$$
\mathrm{S}_{0}=\mathrm{S}_{1}^{*}
$$

Under the RWH, equation (2) is expressed as follows

$$
\begin{aligned}
& \left(1+\mathrm{R}_{\mathrm{P}}^{\$}\right)^{*}=\left[\left(1+\mathrm{R}_{\mathrm{S}}^{\mathrm{DM}}\right) \frac{\mathrm{S}_{1}}{\mathrm{~S}_{0}}\right]^{*} \pm \mathrm{k}\left(\frac{\mathrm{S}_{0}-\mathrm{F}_{0}}{\mathrm{~S}_{0}}\right) \\
& =\left[\left(1+\mathrm{R}_{\mathrm{S}}^{\mathrm{DM}}\right) \frac{\mathrm{S}_{1}}{\mathrm{~S}_{0}}\right]^{*} \pm \mathrm{k}\left(1-\frac{\mathrm{F}_{0}}{\mathrm{~S}_{0}}\right)
\end{aligned}
$$

The traditional belief about investing in international equities has been that foreign equities outperform U.S. equities. Specifically, the expectation of higher returns and lower risk has been the main motivator behind international diversification. Recent empirical evidence by Sinquefield (1996), however, suggests otherwise. He claims that for integrated foreign stock markets such as the French, German, UK, Canadian, Japanese, and the Swiss stock market, the expected (excess) return of each country stock index should be the same.

This claim translates into equal long-term stock index return performance regardless of national origin, when the return is expressed in dollars. If the above claim is correct, then under the UFRH, the specialized investor/speculator will be indifferent between foreign and domestic stock indices with or without forward foreign exchange contracts. Under the RWH, the risk neutral investor/speculator will concentrate on the forward foreign 
exchange component in the expected portfolio return $\left(1+\mathrm{R}_{\mathrm{P}}^{\$}\right)^{*}$. Since the investor wants to maximize $\left(1+\mathrm{R}_{\mathrm{P}}^{\$}\right)^{*}$ (s)he will decide on the foreign stock index that maximizes $\pm \mathrm{k}\left(1-\frac{\mathrm{F}_{0}}{\mathrm{~S}_{0}}\right)$ or max $\mathrm{k}\left|1-\frac{\mathrm{F}_{0}}{\mathrm{~S}_{0}}\right|$. If the expression within the absolute value brackets is negative (positive), then the risk-neutral investor/speculator will sell (buy) the currency of the foreign stock index forward. Since it is almost impossible to have $\frac{F_{0}}{S_{0}}=1$ for all foreign countries in the investor's universe, we expect the temporal composition of the specialized portfolios to be strictly international, i.e., not to include the domestic U.S. stock market index.

Thus, the maximization of $\left(1+\mathrm{R}_{\mathrm{P}}^{\$}\right)^{*}$ under the RWH translates into the following rule-of-thumb:

1. At the beginning of every period the risk-neutral investor/speculator computes $\left|1-\frac{\mathrm{F}_{0}}{\mathrm{~S}_{0}}\right|$ for each foreign exchange forward contract under consideration and selects the contract, and associated foreign stock index, with the $\operatorname{maximum}\left|1-\frac{\mathrm{F}_{0}}{\mathrm{~S}_{0}}\right|$

2. If the expression in the absolute value brackets is negative (positive) the investor buys the associated foreign stock index and sells (buys) the same currency forward.

The size of the notional value of the forward contract relative to the equity investment size, $\mathrm{k}$, depends on the volatility of the foreign exchange changes, the return frequency, institutional constraints, and the monetary constraints of the investor. According to Madura (2000, p. 257), the C \$ showed less volatility than the SF or the J¥ over the period 1974-1998. Further, given that volatility is a negative function of the data frequency, we chose $\mathrm{k}=1$ and 2 only, since we were relegated to working with quarterly data. ${ }^{3}$

If the RWH holds, we expect the strategy of selecting a contract with max $\left|1-\frac{\mathrm{F}_{0}}{\mathrm{~S}_{0}}\right|$ and buying the associated foreign equity index will on average outperform the same foreign stock index without forward contracts. Next we discuss the data source and present the analytical framework for testing the (in)efficiency of the forward exchange market with the time series of actual quarterly portfolio returns generated under the UFRH and the RWH.

\section{THE DATA AND THE ANALYTICAL FRAMEWORK}

\section{The Data}

To analyze the efficiency of specialized international stock indices with forward contracts relative to the same stock indices alone, we developed one period ahead expected spot rates in the 1974.II to 1996.IV period for the following countries (currencies): Canada (C\$), France (FF), Germany (DM), Japan (J¥), Switzerland (SF), and the United Kingdom (BP). The choice of quarterly data was made because of availability. However, quarterly data, besides being non-overlapping, mitigate timing problems associated with higher frequency data.

Since we adopted the U.S. viewpoint, we used the following quarterly time series for our analysis: U.S. money market interest rates, Industrial Share Price Index (ISPI) data for the U.S. and the above six (6) foreign countries, spot exchange rates, and three-month forward rates. The above data were compiled from the International Financial Statistics, a publication of the International Monetary Fund, and are available in the databank that is part of Madura's (2000) textbook. 
Since our original data on spot and forward exchange rates were expressed in U.S. dollars per foreign exchange unit or $\$ / F X$ and since our analysis is performed from a U.S. viewpoint, no conversion of the raw data is needed.

\section{Test of the UFRH}

Relevant expected values for exchange rates and foreign stock index returns are unavailable. We, therefore, assume that the U.S. risk-neutral investor/speculator forecasts based on the UFRH, the average realized specialized portfolio return with forward contracts will not be statistically different from the average specialized portfolio return without forward contracts, as shown in equation (3).

To assess the UFRH, we measure the deviation $d_{t}(t=1, \ldots, n=91)$ between the U.S. investor's return on a portfolio with forwards and the same single market portfolio return without forwards. That is,

$$
\begin{aligned}
& d_{t}=\left[\left(1+R_{S t}^{F X}\right) \frac{S_{t}}{S_{t-1}} \pm k\left(\frac{S_{t}-F_{t-1}}{S_{t-1}}\right)\right]-\left(\left(1+R_{S t}^{F X}\right) \frac{S_{t}}{S_{t-1}}\right) \\
& = \pm k\left(\frac{S_{t}-F_{t-1}}{S_{t-1}}\right)
\end{aligned}
$$

Since returns on portfolios with and without forwards are correlated, we employ the paired t-test for dependent observations to the quarterly variable $d_{t}$ to test whether the UFRH is maintained or rejected. Thus we calculate the statistic

$$
\mathrm{t}=\frac{\overline{\mathrm{d}}-0}{\sigma_{\overline{\mathrm{d}}}}=\frac{\overline{\mathrm{d}}}{\sigma_{\mathrm{d}} / \sqrt{\mathrm{n}}}=\frac{\overline{\mathrm{d}} \sqrt{\mathrm{n}}}{\sigma_{\mathrm{d}}}
$$

where, $\sigma_{\mathrm{d}}\left(\sigma_{\overline{\mathrm{d}}}\right)$ is the standard deviation of $\mathrm{d}_{\mathrm{t}}(\overline{\mathrm{d}}), \overline{\mathrm{d}}$ is the arithmetic mean of $\mathrm{d}_{\mathrm{t}}$ 's or $\overline{\mathrm{d}}=\left(\sum_{\mathrm{t}=1}^{\mathrm{n}} \mathrm{d}_{\mathrm{t}}\right) / \mathrm{n}$, and $\mathrm{n}=$ the number of quarterly observations in the sample. Here $n=91$. For each foreign stock index (and currency), the null hypothesis is

$$
\mathrm{H}_{0}: \mathrm{d}^{*}=0
$$

where $\mathrm{d}^{*}$ refers to the expected value of $\overline{\mathrm{d}}$,

and the alternative hypothesis is

$\mathrm{H}_{1}: \mathrm{d}^{*} \neq 0$

If the null hypothesis is not be rejected, the investor employing the strategy based on the UFRH will be justified in being indifferent between investing in a foreign stock market and investing in same foreign stock market with long or short forwards. 


\section{Test of Equality in Expected Returns for Foreign and Domestic Stock Indices}

As Sinquefield (1996) has shown, if one concentrates his investments in stock indices, international diversification may be unnecessary to a risk neutral investor. To test the equality among stock indices we have to take into account the evidence of positive correlation among country index returns. Indeed, Balvers, Wu, and Gilliland (2000, p. 752), using annual return data from Morgan Stanley Capital International over the period 1970 to 1996, estimated the following betas with the world index for the countries in our universe - Canada: $\beta=0.759$, France: $\beta$ $=1.115$, Germany: $\beta=0.755$, Japan: $\beta=1.321$, Switzerland: $\beta=0.874$, United Kingdom: $\beta=1.312$, and United States: $\beta=0.806$.

The above statistics show that international stock index returns are positively correlated and thus the use of paired t-tests is indicated. Thus, to assess the posited equality of foreign and domestic stock index expected returns, we calculate the deviation $d_{t}(t=1, \ldots, 91$ quarters) between the investor's U.S. stock market index return and the contemporaneous foreign stock market index return based on U.S. dollars:

$$
d_{t}=\left(1+R_{S, t}^{F X}\right) \frac{S_{t}}{S_{t-1}}-\left(1+R_{S, t}^{U S}\right)
$$

In employing the paired t-test for dependent observations to the quarterly variable $d_{t}$ we calculate the $t$ statistic from equation (7) and test the same set of hypotheses as in expression (8). If the null hypothesis is not rejected, then we maintain the hypothesis that there are no differential expected returns for country-specific stock market indices.

\section{Test of the RWH}

If the assumption of equal expected country-specific stock returns is defensible then at every decision time the RWH-based strategist will concentrate on the choice of one forward foreign exchange contract from the set of six different currencies, based on the max $\left|1-\frac{\mathrm{F}_{0}}{\mathrm{~S}_{0}}\right|$ criterion. If the information provided by the criterion has predictive value, then selecting sequentially the forward contract with the max $\left|1-\frac{F_{0}}{S_{0}}\right|$ should provide superior performance on average. Since we expect the above criterion to select different currencies over time, the multi-currency approach associated with the RWH will test the following hypotheses:

If the time-series of realized portfolio returns is based on the max $\left|1-\frac{\mathrm{F}_{0}}{\mathrm{~S}_{0}}\right|$ criterion, then

$\mathrm{H}_{0}: \mathrm{d}^{*}=0$ and $\mathrm{H}_{1}: \mathrm{d}^{*}>0$

Here the $d_{t}$ value $(t=1, \ldots, n=91)$ is defined by equation (6). If the alternative hypothesis in expression (10) is maintained, then the RWH will be preferred to the UFRH.

The significance of the RWH will be tested by the same statistic given in equation (7). The only difference is that the null hypothesis under the UFRH will be tested using a two-tailed test, whereas the null hypothesis under the RWH will be tested using a one-tailed test. 


\section{Measuring Risk and Return in the CAPM Framework}

The literature on international capital markets is copious and most studies assume that markets are segmented, integrated, or partially integrated. Whether U.S. assets are priced domestically or internationally is an empirical question. Fletcher (2001), for example, uses the UK viewpoint and finds that domestic asset pricing models tend to capture more of the time-series predictability in UK stock returns than international models. In addition, for both types of asset pricing models, he employs UK Treasury Bills as proxies for the risk-free asset.

The case of the time-series of portfolio returns generated under the RWH is unusual because it contains data from different foreign stock indices. Since all realized portfolio returns, both under the UFRH and the RWH, are expressed in dollars, we assume that they have been generated by artificial U.S. assets and analyze their risk/return characteristics in two ways. In the first case we assume that the capital markets are segmented and adopt the U.S. stock market index as the market portfolio. In the second case we assume the capital markets are integrated, with the U.S. stock market index as only an important component of the world market portfolio. We assume that the "world" market portfolio return is proxied by the arithmetic average of the contemporaneous returns of the Canadian, German, British, French, Swiss, Japanese, and U.S. stock indices.

To determine the systematic risk, or beta, $\beta_{\mathrm{P}}$, of the portfolios under consideration and their degree of superior, or inferior, performance, $\alpha_{\mathrm{P}}$, in the CAPM context, we use the following characteristic line regression model:

$$
\mathrm{R}_{\mathrm{Pt}}-\mathrm{r}_{\mathrm{t}}=\alpha_{\mathrm{P}}+\beta_{\mathrm{P}}\left(\mathrm{R}_{\mathrm{mt}}-\mathrm{r}_{\mathrm{t}}\right)+\varepsilon_{\mathrm{Pt}}
$$

where:

$$
\begin{aligned}
& \alpha_{\mathrm{P}}=\begin{array}{l}
\text { a return component that quantifies the magnitude of the forward } \\
\text { exchange rate pricing error à la CAPM, }
\end{array} \\
& \beta_{\mathrm{P}}=\begin{array}{l}
\text { the slope coefficient that measures the sensitivity of portfolio } \\
\text { returns to movements in the US or "world" market portfolio, } \mathrm{R}_{\mathrm{mt}},
\end{array} \\
& \varepsilon_{\mathrm{Pt}}=\text { a random disturbance, } \\
& \mathrm{r}_{\mathrm{t}}=90 \text {-day US money market rate, a proxy for the risk-free asset return. }
\end{aligned}
$$

As previously mentioned, empirical evidence by Balvers, Wu, and Gilliland (2000, p. 752) and others shows that the systematic risk, or beta, of the first return component in equation (A.5) is positive and gravitates around one. Similarly, empirical evidence by Mark (1988) and others suggests that the beta of the second "return" component in equation (A.5) should be near zero and, generally, statistically insignificant. Given $\beta_{P}$, if $\alpha_{P}>0\left(\alpha_{P}<0\right)$ the performance of the associated portfolio is deemed superior (inferior). Under the UFRH the hypotheses to be tested are that $\alpha_{\mathrm{P}}=0$ and $\beta_{\mathrm{P}}>0$. Under the RWH, the associated expectations for portfolios selected by maximizing $\left|1-\frac{\mathrm{F}_{0}}{\mathrm{~S}_{0}}\right|$ over time are that, $\alpha_{\mathrm{P}}>0$ and $\beta_{\mathrm{P}}>0$. In the next section, we provide empirical evidence on the assumptions and claims advanced in this paper.

\section{EMPIRICAL RESULTS}

First we examine quarterly portfolio returns that are generated under the UFRH. The first observation is obtained when the investor buys a foreign stock market index and is long, or short, the corresponding foreign exchange forward contract at the end of 1974.I. The last observation is generated when the investor selects the portfolio at the end of 1996.III. Panel A. of Table 1 reports the results of the paired $\mathrm{t}$-tests for the UFRH when $\mathrm{k}=$ +1.0 and when the same currency forward contracts are used throughout the 91 -quarter sample period. ${ }^{4}$ We observe that with the exception of the Canadian stock index, the average deviation, $\overline{\mathrm{d}}$, is generally positive but not statistically different from zero. The test then fails to reject the null hypothesis of the long-term (i.e., over a 23-year period) unbiasedness of the forward rate. But how strong is this evidence? From expression (8) we notice that the alternative 
hypothesis, $\mathrm{H}_{1}: \mathrm{d}^{*} \neq 0$, does not specify a competing model and thus has little power. In this situation, failure to reject the null hypothesis does not tell us much. Panel B of Table 1 offers strong evidence that when the alternative is the RWH, it convincingly rejects the null UFRH. Indeed when the multi-currency/country strategy applies the max $\left|1-\frac{\mathrm{F}_{0}}{\mathrm{~S}_{0}}\right|$ rule-of-thumb, the average difference $\overline{\mathrm{d}}$ is $3.25 \%$ per quarter and significant at the .001 level. Since the null hypothesis in expression (10) identifies the UFRH as the model to be contrasted to the alternative hypothesis of the RWH, the significant outperformance of the RWH-based rule-of-thumb suggests that the forward rate is an inferior estimator of the future spot rate and that the information the max $\left|1-\frac{\mathrm{F}_{0}}{\mathrm{~S}_{0}}\right|$ rule conveys is incompletely exploited by the market. It is interesting to compare the statistical findings of Table 1 with actual performance results from the same strategies in question by utilizing a multi-period index of performance under sequential reinvestment.

Table 1

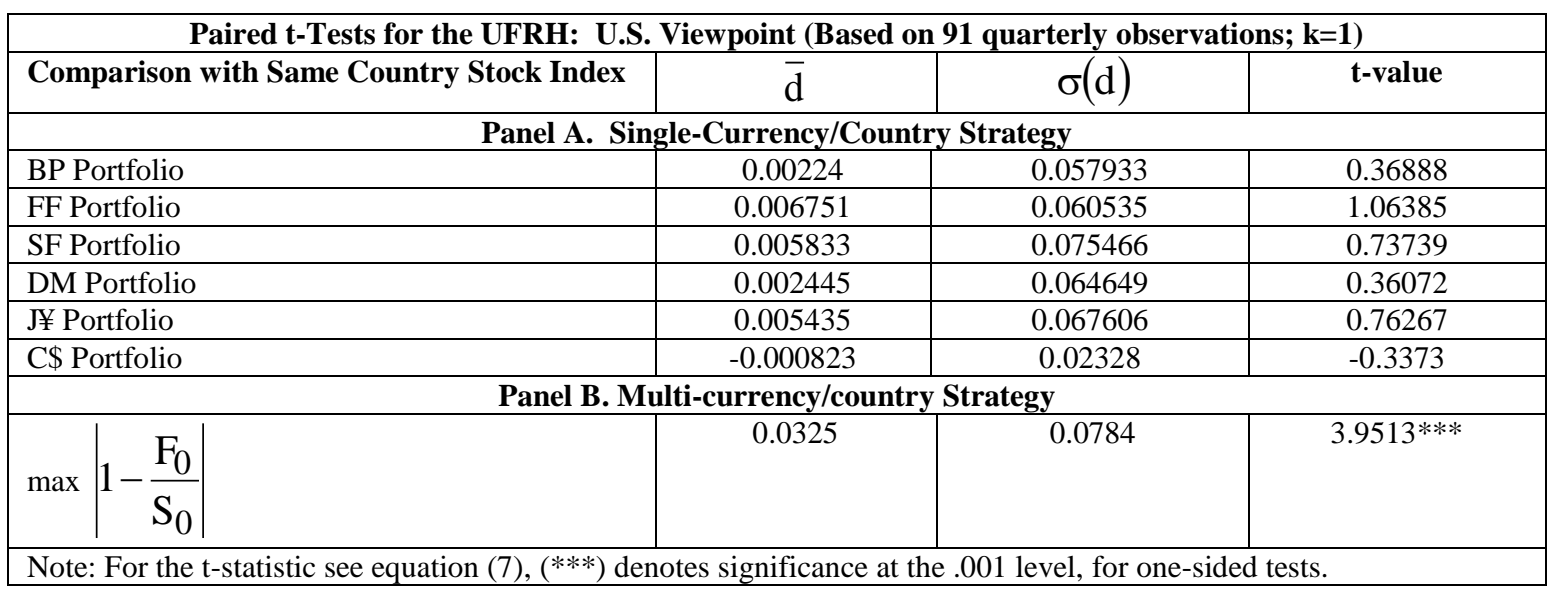

Let us define terminal wealth as

$\mathrm{W}_{\mathrm{T}}=\mathrm{W}_{0}\left(1+\mathrm{R}_{\mathrm{P} 1}\right)\left(1+\mathrm{R}_{\mathrm{P} 2}\right) \ldots\left(1+\mathrm{R}_{\mathrm{PT}}\right)=\mathrm{W}_{0} \prod_{\mathrm{t}=1}^{\mathrm{T}}\left(1+\mathrm{R}_{\mathrm{Pt}}\right)$

where:

$\mathrm{W}_{0}=$ initial wealth, here assumed to be equal to $\$ 1$, and

$\mathrm{T}=1, \ldots, \mathrm{n}=91$ quarters.

Figure 1 shows the terminal wealth (or Index Value) over the period end 1974.I-end 1996.IV of investing sequentially either in the UK stock market index, or the UK stock index plus a long (i.e. $\mathrm{k}=1,2)$ or a short $(\mathrm{k}=-1,-2)$ position in a BP forward contract. The index values are measured on the vertical axis and time is in quarter-year intervals on the horizontal axis. Figures 2 through 6 reflect the same information when the foreign currency contract involves the French Franc, the Swiss Franc, the German Mark, the Japanese Yen, and the Canadian Dollar, respectively. In figure 1, we observe both positive and negative deviations in individual periods or clusters of several periods. However, the general secular trend is unmistakably upward in terminal wealth values. 


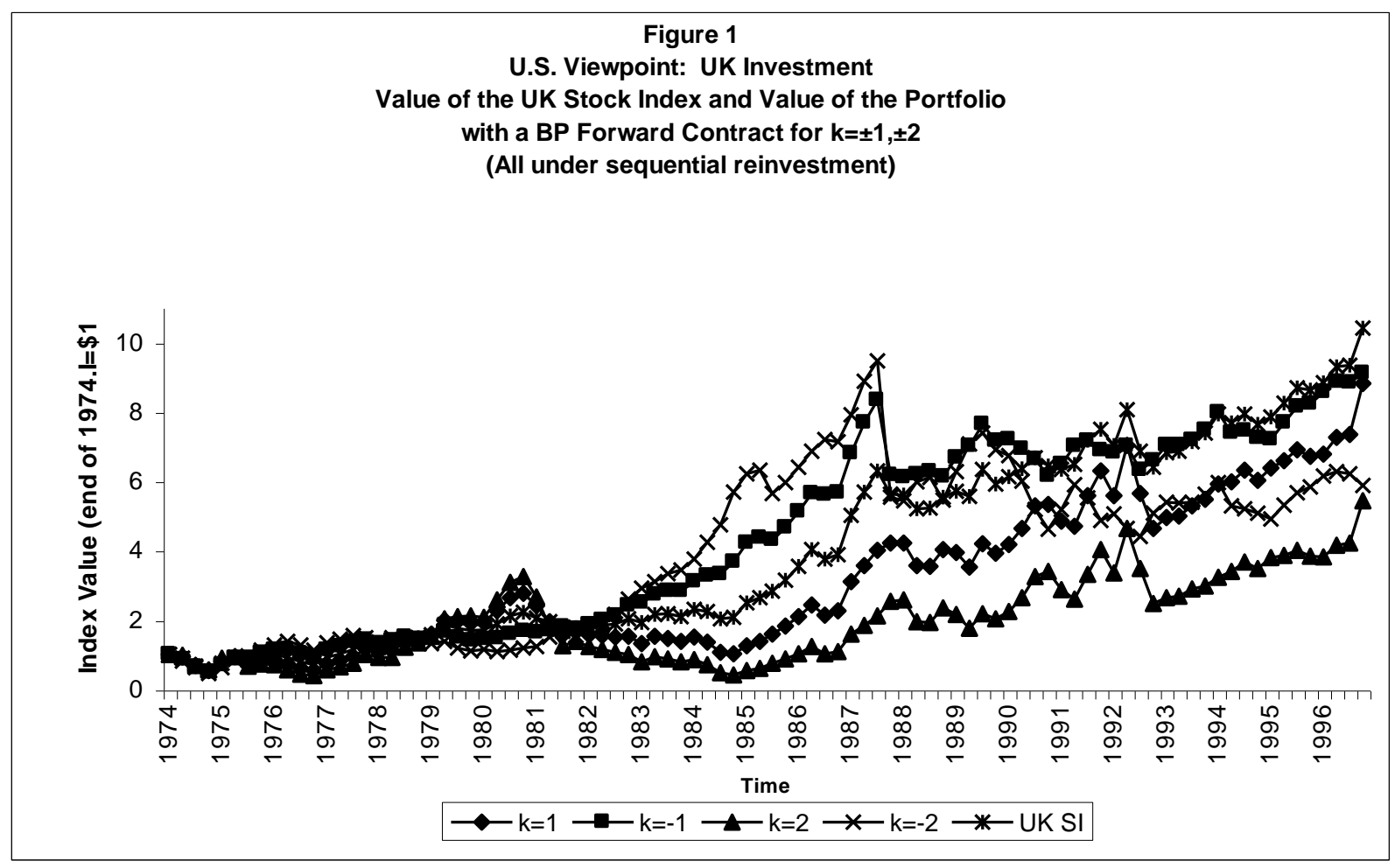

The same general result is found by perusing figures 2 through 6 . Therefore, it can be argued that even though the UFRH performs poorly in any individual period or cluster of periods, over extended periods of time it appears that the UFRH generally holds so that both the foreign stock index and the portfolio of same stock index with forward contracts exhibit the same long-run, secular tendencies by producing similar terminal wealth values.

Figure 7 also plots the Index value of the max $\left|1-\frac{F_{0}}{S_{0}}\right|$ multi-currency/country strategy as a function of time. To account for the sizeable disparities in final wealth, we express the vertical axis numbers in logarithmic terms. It is clear that as time progresses, the spread between terminal wealth $\mathrm{W}_{\mathrm{T}}$ of the $\max \left|1-\frac{\mathrm{F}_{0}}{\mathrm{~S}_{0}}\right|$ multi-currency/country portfolio and that of same multi-currency/country portfolio without forwards becomes wider and wider in favor of the $\max \left|1-\frac{\mathrm{F}_{0}}{\mathrm{~S}_{0}}\right|$ multi-currency/country portfolio. In figure 7, the contrast between the multi-currency/country portfolio without forward contracts and the same portfolio with forwards is more dramatic when $\mathrm{k}=2$.

It is also interesting to compare the performance of the various investment strategies under the UFRH and the RWH-based max $\left|1-\frac{\mathrm{F}_{0}}{\mathrm{~S}_{0}}\right|$ by use of the annualized geometric mean return (or compound annual return) metric. The formula for the annualized geometric return over the entire sample period of 91 quarters (or 22.75 years) is given below: 
$\mathrm{GM}_{\mathrm{P}}=\left[\left(1+\mathrm{R}_{\mathrm{P} 1}\right)\left(1+\mathrm{R}_{\mathrm{P} 2}\right) \ldots\left(1+\mathrm{R}_{\mathrm{P} 91}\right)\right]^{\frac{4}{91}}-1$

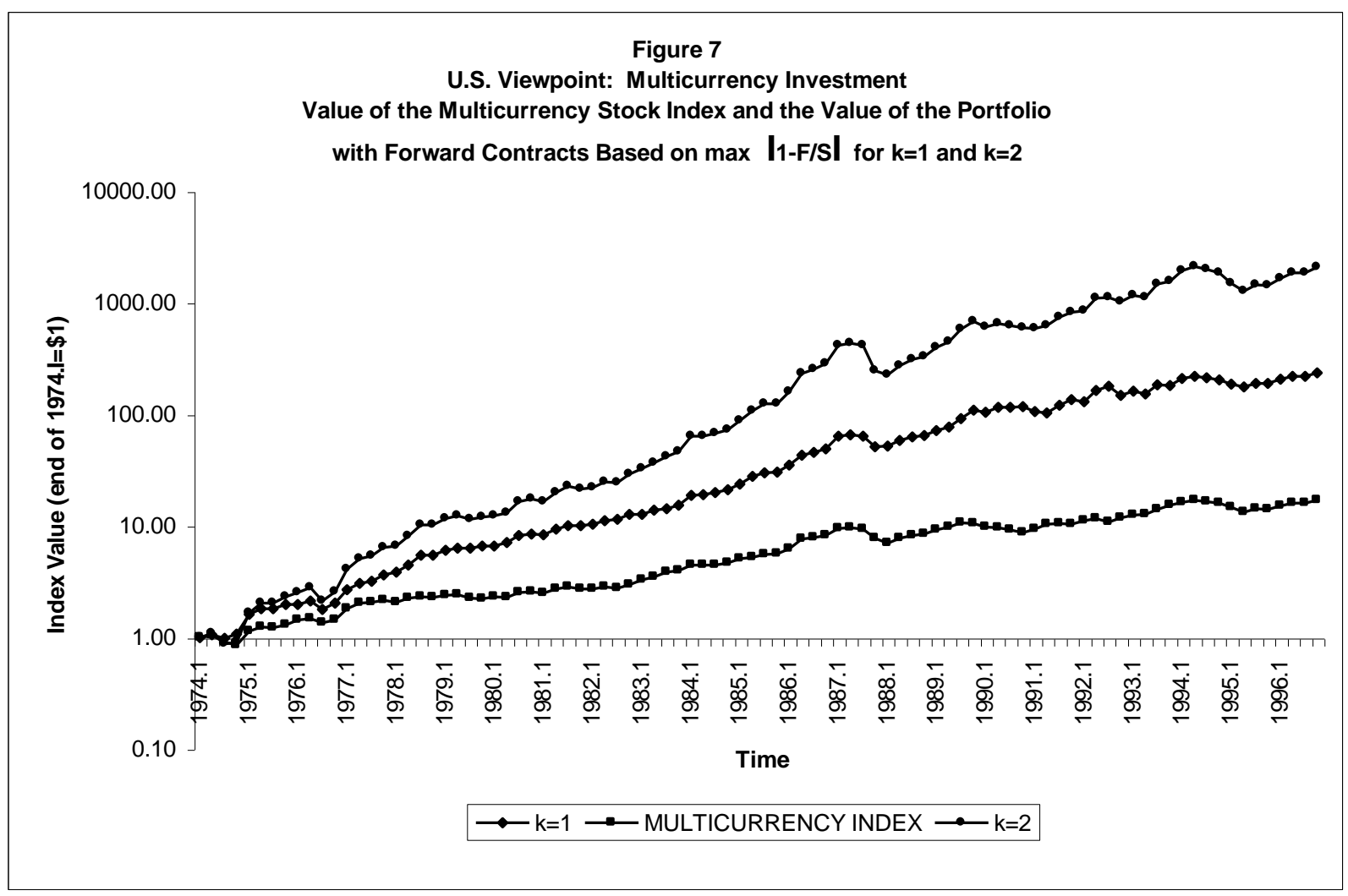

In Table 2, we report the geometric mean returns for the U.S. stock index, the single-currency/country stock indices, the same indices with forward contracts when $\mathrm{k}= \pm 1$ and \pm 2 , the multi-currency/country index without forwards and the multi-currency/country index with $\mathrm{k}=1$ and $\mathrm{k}=2$. As expected, the single-currency/country portfolios perform like the same portfolios with forward contracts, in general. Further, comparing the geometric mean returns of stock indices without forward contracts, we see that the single-currency/country indices, the multicurrency/country stock indices and the U.S. stock index are not dissimilar. Finally, the compound annual return of the $\max \left|1-\frac{\mathrm{F}_{0}}{\mathrm{~S}_{0}}\right|$ strategy with $\mathrm{k}=1$ is a very impressive $27 \%$ whereas the compound annual return of the strategy with $\mathrm{k}$ $=2$ is a stratospheric $40 \%$. Though we do not consider transactions costs in this paper, it is clear that normal levels of transactions fees, which other authors using more frequent trading have estimated to be between $1.62 \%$ to $2.6 \%$ annually, ${ }^{5}$ will not erode such impressive annualized returns.

In Table 3, we report the results of testing the hypothesis of equal country-specific stock returns. Using the $d_{t}$ values from equation (9) we calculate the t-statistic from equation (7) for each foreign index - U.S. index combination. As Panel A shows, we do not reject the null hypothesis of long-term absence of differential expected returns for country-specific stock market indices. This conclusion corroborates the observation of the similarity of geometric means and terminal values from Table 2, when single-currency/country stock indices are compared to the U.S. stock index. 


\begin{tabular}{|c|c|c|c|c|c|c|c|c|c|c|}
\hline \multicolumn{11}{|c|}{$\begin{array}{l}\text { Table } 2 \\
\text { Terminal Wealth, TW, and Geometric Mean Returns, GM, for Time Series Generated Under the UFRH and the RWH : } \\
\text { U.S. Viewpoint (Based on } 91 \text { Quarters or } 22.75 \text { Years) }\end{array}$} \\
\hline \multicolumn{11}{|c|}{ Panel A. Single Currency/country Strategies } \\
\hline & & & \multicolumn{2}{|c|}{$\mathrm{k}=1$} & \multicolumn{2}{|c|}{$\mathrm{k}=-1$} & \multicolumn{2}{|c|}{$\mathbf{k}=\mathbf{2}$} & \multicolumn{2}{|c|}{$\mathrm{k}=-2$} \\
\hline $\begin{array}{l}\text { Time Series } \\
\text { Description }\end{array}$ & TW & GM & TW & GM & TW & GM & TW & GM & TW & GM \\
\hline \$ Stock Index & $\$ 7.9950$ & $9.57 \%$ & & & & & & & & \\
\hline $\begin{array}{l}\mathrm{C} \$ \text { (no } \\
\text { forwards) }\end{array}$ & $\$ 3.0653$ & $5.05 \%$ & & & & & & & & \\
\hline $\mathrm{C} \$+$ Forwards & & & $\$ 2.6019$ & $4.29 \%$ & $\$ 3.3537$ & $5.46 \%$ & $\$ 2.1264$ & $3.37 \%$ & $\$ 3.5298$ & $5.70 \%$ \\
\hline $\begin{array}{l}\text { FF (no } \\
\text { forwards) }\end{array}$ & $\$ 6.2574$ & $8.39 \%$ & & & & & & & & \\
\hline FF + Forwards & & & $\$ 7.2424$ & $9.09 \%$ & $\$ 3.7966$ & $6.04 \%$ & $\$ 5.7641$ & $8.00 \%$ & $\$ 1.6043$ & $2.10 \%$ \\
\hline $\begin{array}{l}\mathrm{SF}(\text { no } \\
\text { forwards) }\end{array}$ & $\$ 10.5807$ & $10.93 \%$ & & & & & & & & \\
\hline SF + Forwards & & & $\$ 10.0235$ & $10.66 \%$ & $\$ 6.7357$ & $8.74 \%$ & $\$ 5.6751$ & $7.93 \%$ & $\$ 2.4745$ & $4.06 \%$ \\
\hline $\begin{array}{l}\mathrm{DM} \text { (no } \\
\text { forwards) }\end{array}$ & $\$ 6.4654$ & $8.55 \%$ & & & & & & & & \\
\hline DM + Forwards & & & $\$ 5.0490$ & $7.38 \%$ & $\$ 5.5948$ & $7.86 \%$ & $\$ 2.5907$ & $4.27 \%$ & $\$ 3.2684$ & $5.34 \%$ \\
\hline $\begin{array}{l}\text { J¥ (no } \\
\text { forwards) }\end{array}$ & $\$ 13.0076$ & $12.08 \%$ & & & & & & & & \\
\hline J¥ + Forwards & & & $\$ 12.4738$ & $11.87 \%$ & $\$ 9.2552$ & $10.40 \%$ & $\$ 8.0683$ & $9.72 \%$ & $\$ 4.4276$ & $6.84 \%$ \\
\hline $\begin{array}{l}\mathrm{BP} \text { (no } \\
\text { forwards) }\end{array}$ & $\$ 10.4205$ & $9.29 \%$ & & & & & & & & \\
\hline BP + Forwards & & & $\$ 8.8210$ & $10.04 \%$ & $\$ 9.1110$ & $10.20 \%$ & $\$ 5.4432$ & $7.73 \%$ & $\$ 5.8725$ & $8.09 \%$ \\
\hline \multicolumn{11}{|c|}{ Panel B. Multi-currency/country Strategy } \\
\hline $\max \left|1-\frac{\mathrm{F}_{0}}{\mathrm{~S}_{0}}\right|$ & & & $\$ 233.51$ & $27.09 \%$ & & & $\$ 2074.08$ & $39.89 \%$ & & \\
\hline $\begin{array}{l}\text { Multi-currency } \\
\text { Unhedged }\end{array}$ & $\$ 16.8704$ & $13.22 \%$ & & & & & & & & \\
\hline
\end{tabular}

\begin{tabular}{|c|c|c|c|}
\hline \multicolumn{4}{|c|}{$\begin{array}{c}\text { Table } 3 \\
\text { Paired t-tests for the Expected Stock Index Return Equalities: } \\
\text { U.S. Viewpoint (Based on 91 quarterly observations) } \\
\end{array}$} \\
\hline Comparison with U.S. Stock Index Returns & $\overline{\mathrm{d}}$ & $\sigma(d)$ & t-value \\
\hline \multicolumn{4}{|c|}{ Panel A. Single-Currency Strategy } \\
\hline Canadian Stock Index & -0.00998 & 0.065252 & -1.45829 \\
\hline French Stock Index & 0.000631 & 0.110392 & 0.054525 \\
\hline German Stock Index & -0.00115 & 0.100925 & -0.10868 \\
\hline Japanese Stock Index & -0.00355 & 0.156746 & -0.21585 \\
\hline Swiss Stock Index & 0.004003 & 0.099923 & 0.382166 \\
\hline British Stock Index & 0.005671 & 0.100227 & 0.539764 \\
\hline \multicolumn{4}{|c|}{ Panel B. Multi-currency Strategy } \\
\hline Multi-currency/country Index Alone & \begin{tabular}{r|r}
0.014749 \\
\end{tabular} & 0.099894 & 1.4085 \\
\hline
\end{tabular}

Panel B in Table 3 also tests the hypothesis of equality between expected multi-currency/country stock index returns and U.S. stock index returns. Again, the resulting t-value does not reject the null hypothesis.

Figure 8 also plots the Index Values of all single-currency/country stock indices as a function of time. The performance of all foreign and domestic stock indices are similar and thus corroborate the observation of Geometric Mean Return, GM, and Terminal Wealth, TW, similarity among the equity indices under consideration from Table 2. 


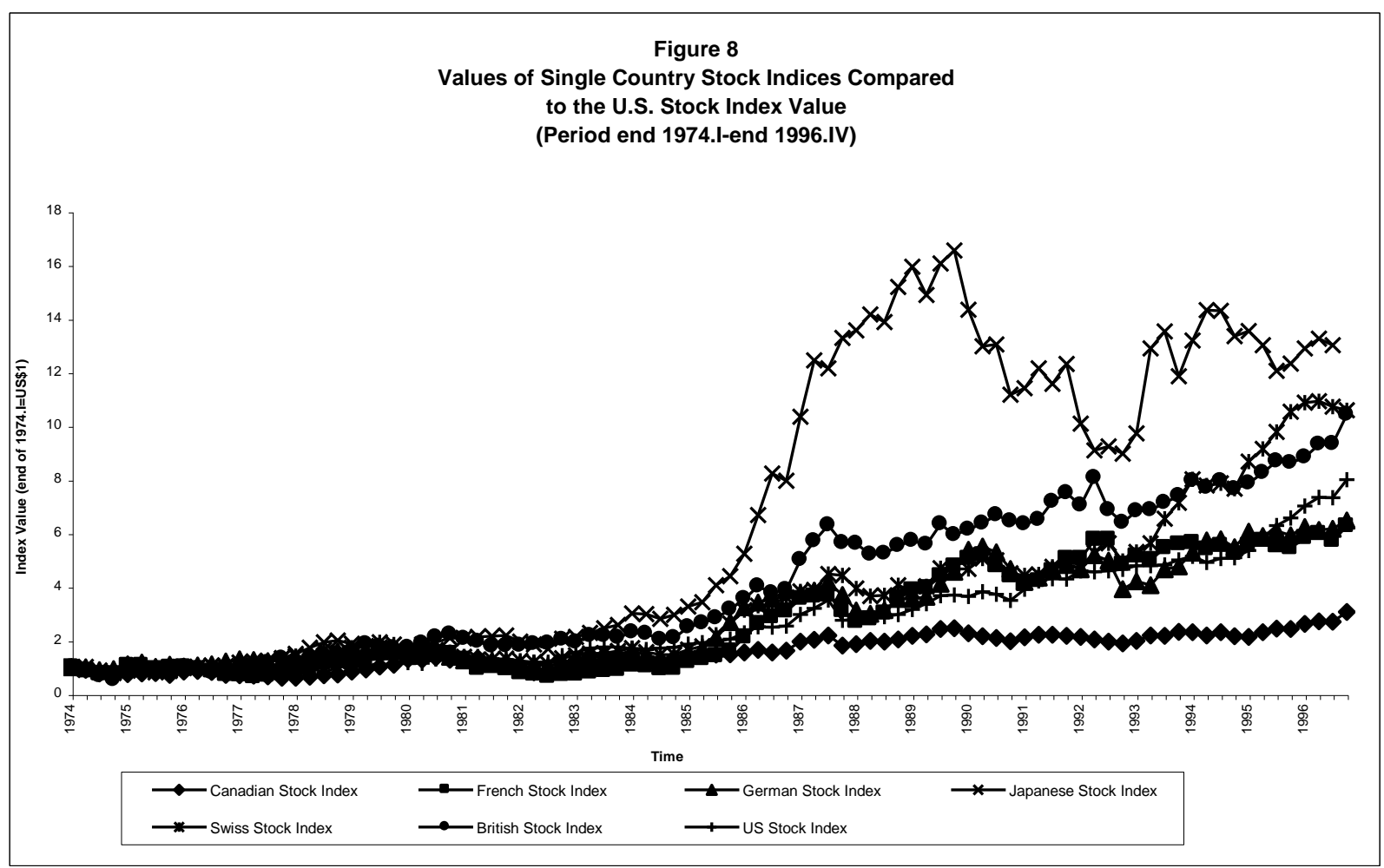

Finally, it is also interesting to quantify the systematic riskiness, $\beta_{\mathrm{P}}$, and abnormal returns, $\alpha_{\mathrm{P}}$, if any, of each of the strategies in question, within the CAPM framework. We use the conventional characteristic line model (see equation (11)) and Table 4 records the results. With the exception of the C\$ stock market, the international CAPM explains the observed time-series of stock index with forwards returns much better than the domestic CAPM. The same applies to the multi-currency/country stock index with forwards time-series. Again, as expected the intercept $\alpha_{P}$ is statistically insignificant for all single-currency/country indices, regardless of "market" portfolio used. As for the beta coefficient, the domestic CAPM produces betas that are defensive (i.e. have value lower than one) and some are statistically insignificant. When the international CAPM is used, however, all betas are statistically significant and, with the exception of the $\mathrm{C} \$$ stock index, have values greater than one.

As for the multi-currency/country strategies, their betas increase when the international CAPM is used and, with the exception of the domestic beta when $\mathrm{k}=1$, are statistically significant. As for the alphas, $\alpha_{\mathrm{P}}$, they are all statistically significant and positive, with values higher (lower) within the domestic (international) CAPM framework, as expected. ${ }^{6}$ When $\mathrm{k}=1$, the $\max \left|1-\frac{\mathrm{F}_{0}}{\mathrm{~S}_{0}}\right|$ strategy produces $\left\{\alpha_{\mathrm{P}}=0.047, \beta_{\mathrm{P}}=0.262\right\}$ statistics with the domestic CAPM and $\left\{\alpha_{P}=0.041, \beta_{P}=0.893\right\}$ statistics with the international CAPM. When the portfolios are levered, i.e. for $\mathrm{k}=2$, the associated $\left\{\alpha_{\mathrm{P}}, \beta_{\mathrm{P}}\right\}$ statistics are more impressive yet. Specifically, the alpha coefficient from the domestic (international) CAPM is $0.0766(0.0685)$ per quarter or more than $4 \times 0.076=30.6 \%$ ( $4 \times 0.0685=27.4 \%$ ) when annualized. Again these are results that far outweigh the potential transactions fee differentials between strategies.

\section{CONCLUDING COMMENTS}

In this paper we consider an investment universe of six major foreign equity markets and their associated forward currency markets. Our analysis allows us to make several statistically justified statements. 
Under the UFRH we do not reject the hypothesis that long-term, the average country-specific stock index return is no different from same with long or short foreign exchange forward positions. The above result obtains in the absence of a specific competing alternative hypothesis.

We do not reject the hypothesis that the long-term performance in dollar terms of foreign stock indices is no different from that of the U.S. stock index. Under the assumptions of risk-neutrality and the random walk, we devise a rule-of thumb, i.e., the max $\left|1-\frac{\mathrm{F}_{0}}{\mathrm{~S}_{0}}\right|$ rule, which, in direct competition with the UFRH, empirically produces statistically and economically superior performance. Eun and Resnick (1988) point out that the gains from international stock portfolio diversification are enhanced when the uncertainties from foreign exchange (through hedging) and other portfolio parameters are controlled. Our rule-of-thumb for the selection of specialized international equity portfolios exhibits no parameter uncertainties.

Most tests of forward market efficiency employ regression methodologies to examine the relationship between the future spot rate, or change, and the past forward rate, or change. Because there is no simple relation between regression results and profit opportunities in forward markets, a contribution of our paper was to link the forward rate bias $\left(\frac{\mathrm{S}_{1}^{*}-\mathrm{F}_{0}}{\mathrm{~S}_{0}}\right)$ to profit opportunities by identifying, via the max $\left|1-\frac{\mathrm{F}_{0}}{\mathrm{~S}_{0}}\right|$ criterion, the direction of the bias in advance. Our model is a direct test of forward market informational efficiency since it examines whether unusual opportunities exist in this market. The model highlights the significant benefit of searching for extreme values of $\left|1-\frac{\mathrm{F}_{0}}{\mathrm{~S}_{0}}\right|$ across many currencies. Our model exploits the bias in the forward premium and its success gives credence to Bilson's (1981) claim that the bias appears to be even greater when the forward premium takes on extreme values, say $\left|\ln \frac{\mathrm{F}}{\mathrm{S}}\right|>0.10$. 


\begin{tabular}{|c|c|c|c|c|c|c|c|c|c|c|c|c|}
\hline \multicolumn{13}{|c|}{\begin{tabular}{|c|} 
Table 4: REGRESSION-BA \\
\end{tabular}} \\
\hline \multicolumn{13}{|c|}{$\left(\mathrm{R}_{\mathrm{Pt}}-\mathrm{R}_{\mathrm{t}}\right)=\alpha_{\mathrm{P}}+\beta_{\mathrm{P}}\left(\mathrm{R}_{\mathrm{mt}}-\mathrm{R}_{\mathrm{t}}\right)+\varepsilon_{\mathrm{Pt}}$} \\
\hline \multicolumn{13}{|c|}{ Panel A. Single-Currency/Country } \\
\hline & \multicolumn{6}{|c|}{$\mathrm{Rm}=$ US Stock Index Return } & \multicolumn{6}{|c|}{$\mathrm{Rm}=$ "World" Stock Index Return } \\
\hline & \multicolumn{3}{|c|}{$\mathrm{K}=1$} & \multicolumn{3}{|c|}{$\mathrm{K}=2$} & \multicolumn{3}{|c|}{$\mathrm{K}=1$} & \multicolumn{3}{|c|}{$\mathrm{K}=2$} \\
\hline Currency & $\alpha_{P}$ & $\beta_{\mathrm{P}}$ & Adj. $R^{2}$ & $\alpha_{P}$ & $\beta_{\mathrm{P}}$ & Adj. $R^{2}$ & $\alpha_{P}$ & $\beta_{\mathrm{P}}$ & Adj. $R^{2}$ & $\alpha_{P}$ & $\beta_{\mathrm{P}}$ & $\begin{array}{l}\text { Adj. } \\
\mathrm{R}^{2}\end{array}$ \\
\hline BP & $\begin{array}{l}0.0115 \\
(0.0145) \\
{[0.7943]} \\
\end{array}$ & $\begin{array}{l}0.5392 \\
(0.1985) \\
{[2.7161]^{*}}\end{array}$ & 0.0662 & $\begin{array}{l}0.0144 \\
(0.0197) \\
{[0.7321]} \\
\end{array}$ & $\begin{array}{l}0.4494 \\
(0.2705) \\
{[1.6615]} \\
\end{array}$ & 0.0192 & $\begin{array}{l}0.0020 \\
(0.1038) \\
{[0.1953]}\end{array}$ & $\begin{array}{l}1.5429 \\
(0.1546) \\
{[9.9831]^{* *}}\end{array}$ & 0.5229 & $\begin{array}{l}0.0016 \\
(0.0152) \\
{[0.1042]}\end{array}$ & $\begin{array}{l}l .8458 \\
(0.2263) \\
{[8.1580]^{* *}}\end{array}$ & 0.4214 \\
\hline FF & $\begin{array}{l}0.0116 \\
(0.0157) \\
{[0.7378]}\end{array}$ & $\begin{array}{l}0.4559 \\
(0.2160) \\
{[2.1109]^{\mathrm{a}}}\end{array}$ & 0.0370 & $\begin{array}{l}0.0192 \\
(0.0213) \\
{[0.9015]}\end{array}$ & $\begin{array}{l}0.3538 \\
(0.2915) \\
{[1.2135]}\end{array}$ & 0.0052 & $\begin{array}{l}-0.0006 \\
(0.0101) \\
{[-0.0605]}\end{array}$ & $\begin{array}{l}1.7807 \\
(0.1499) \\
{[11.877]^{* *}}\end{array}$ & 0.6088 & $\begin{array}{l}0.0029 \\
(0.0151) \\
{[0.1906]}\end{array}$ & $\begin{array}{l}2.1486 \\
(0.2249) \\
{[9.5501]^{* *}}\end{array}$ & 0.5006 \\
\hline $\mathrm{C} \$$ & $\begin{array}{l}-0.0093 \\
(0.0077) \\
{[0.1052]}\end{array}$ & $\begin{array}{l}0.7834 \\
(0.1052) \\
{[7.4465]^{* *}}\end{array}$ & 0.3769 & $\begin{array}{l}-0.0105 \\
(0.0093) \\
{[-1.1290]}\end{array}$ & $\begin{array}{l}0.8319 \\
(0.1277) \\
{[6.5148]^{* *}}\end{array}$ & 0.3153 & $\begin{array}{l}-0.0129 \\
(0.0080) \\
{[-1.2880]} \\
\end{array}$ & $\begin{array}{l}0.7988 \\
(0.1189) \\
{[6.7164]^{* *}}\end{array}$ & 0.3289 & $\begin{array}{l}-0.0115 \\
(0.0096) \\
{[-1.1902]} \\
\end{array}$ & $\begin{array}{l}0.8406 \\
(0.1436) \\
{[5.8523]^{* *}}\end{array}$ & 0.2698 \\
\hline J¥ & $\begin{array}{l}0.0187 \\
(0.0159) \\
{[1.1716]}\end{array}$ & $\begin{array}{l}0.3325 \\
(0.2186) \\
{[1.5213]}\end{array}$ & 0.0256 & $\begin{array}{l}0.0244 \\
(0.0225) \\
{[1.0834]}\end{array}$ & $\begin{array}{l}0.2939 \\
(0.3087) \\
{[0.9522]}\end{array}$ & 0.0102 & $\begin{array}{l}0.0095 \\
(0.0127) \\
{[0.7458]}\end{array}$ & $\begin{array}{l}1.3988 \\
(0.1892) \\
{[7.3943]^{* *}}\end{array}$ & 0.3832 & $\begin{array}{l}0.0114 \\
(0.0185) \\
{[0.6162]}\end{array}$ & $\begin{array}{l}1.8234 \\
(0.2759) \\
{[6.6096]^{* *}}\end{array}$ & 0.3242 \\
\hline SF & $\begin{array}{l}0.0179 \\
(0.0153) \\
{[1.1674]} \\
\end{array}$ & $\begin{array}{l}-0.0376 \\
(0.2105) \\
{[-0.1786]}\end{array}$ & -0.0109 & $\begin{array}{l}0.0261 \\
(0.0225) \\
{[1.1590]}\end{array}$ & $\begin{array}{l}-0.3419 \\
(0.3091) \\
{[-1.1064]}\end{array}$ & 0.0025 & $\begin{array}{l}0.0061 \\
(0.0123) \\
{[0.4929]} \\
\end{array}$ & $\begin{array}{l}1.3062 \\
(0.1828) \\
{[7.1460]^{* *}}\end{array}$ & 0.3574 & $\begin{array}{l}0.0090 \\
(0.0196) \\
{[0.4615]} \\
\end{array}$ & $\begin{array}{l}1.6263 \\
(0.2919) \\
{[5.5720]^{* *}}\end{array}$ & 0.2503 \\
\hline $\mathrm{DM}$ & $\begin{array}{l}-0.0071 \\
(0.0285) \\
{[-0.2498]}\end{array}$ & $\begin{array}{l}0.0004 \\
(0.0005) \\
{[0.6588]}\end{array}$ & -0.0063 & $\begin{array}{l}-0.0111 \\
(0.0404) \\
{[-0.2757]}\end{array}$ & $\begin{array}{l}0.0005 \\
(0.0008) \\
{[0.6498]}\end{array}$ & -0.0065 & $\begin{array}{l}-0.0027 \\
(0.0110) \\
{[-0.2452]}\end{array}$ & $\begin{array}{l}1.3304 \\
(0.1642) \\
{[8.1009]^{* *}}\end{array}$ & 0.4179 & $\begin{array}{l}-0.0035 \\
(0.0167) \\
{[-0.2087]} \\
\end{array}$ & $\begin{array}{l}1.6951 \\
(0.2492) \\
{[6.8022]^{* *}}\end{array}$ & 0.3347 \\
\hline \multicolumn{13}{|c|}{ Panel B. Multi-currency/country } \\
\hline $\begin{array}{l}\operatorname{Max} \\
\left|1-\frac{F}{S}\right|\end{array}$ & $\begin{array}{l}0.0469 \\
(0.0111) \\
{[4.2405]^{*}} \\
*\end{array}$ & $\begin{array}{l}0.2618 \\
(0.1516) \\
{[1.7274]}\end{array}$ & 0.0216 & $\begin{array}{l}0.0766 \\
(0.0172) \\
{[4.4503]^{* *}}\end{array}$ & $\begin{array}{l}0.7392 \\
(0.2360) \\
{[3.1317]^{* *}}\end{array}$ & 0.3683 & $\begin{array}{l}0.0410 \\
(0.0093) \\
{[4.4052]^{* *}}\end{array}$ & $\begin{array}{l}0.8934 \\
(0.1386) \\
{[6.4476]^{* *}}\end{array}$ & 0.3107 & $\begin{array}{l}0.0685 \\
(0.0144) \\
{[4.7637]^{* *}}\end{array}$ & $\begin{array}{l}1.5657 \\
(0.2141) \\
{[7.3129]^{* *}}\end{array}$ & 0.0891 \\
\hline
\end{tabular}

Note: $(*, * *)$ denotes significance at the $(.01, .0001)$ levels respectively. 
As previously mentioned, Grinold and Meese (2000, p. 58) state that "It is common practice to ignore hedging in determining the fraction of assets to be invested internationally and then ask whether those assets should be hedged." In sharp contrast, a second contribution of our paper is to successfully turn this common practice on its head by first selecting the foreign currency and then the same-currency foreign equity index. Only then is the portfolio statistically tested for abnormal excess returns. In other words, the success of the max $\left|1-\frac{\mathrm{F}_{0}}{\mathrm{~S}_{0}}\right|$ rule-of-thumb is based on first selecting a forward foreign exchange contract and then considering the selection of the associated samecurrency foreign equity index a residual decision.

Finally, our simple trading strategy applied with quarterly data results in abnormal returns that are economically as well as statistically significant for the 1974-1996 sample period. This suggests that investors do not efficiently use all freely available information to predict future spot rates. They seem to systematically misestimate the information provided by the current spot rate. Maybe the market will be less slow to exploit these opportunities in the future.

\section{SUGGESTIONS FOR FUTURE RESEARCH}

We recommend that future work in this area might include a re-examination of our rule-of-thumb with say the Australian dollar (A\$) and the Euro (€) replacing the defunct German Mark (DM) and French Franc (FF). Finally, we should test the degree of success of the rule-of-thumb with data frequencies other than quarterly.

\section{ENDNOTES}

1. The consensus in the financial literature about the superiority of the naïve martingale, i.e. the driftless random walk, is reflected in the following statement by Diebold, Gardeazabal and Yilmaz (1994, p. 727): "In short, financial economists have yet to develop an exchange rate model, structural or nonstructural, with ex ante predictive performance statistically significantly better than a naïve martingale."

2. $\quad$ See for example Fama (1984), Frankel and Froot (1987), and Froot and Frankel (1989).

3. The International Financial Statistics publication does not report data of many frequencies. Our trading rule, unlike many others, requires the availability of forward contract prices in establishing our investment and this caused us to use quarterly data.

4. We do not report results when $\mathrm{k}=+2$ because the $\mathrm{t}$-values are the same. Indeed, inspection of equation (6) shows that when $\mathrm{k}=+2, \overline{\mathrm{d}}$ and $\sigma_{\mathrm{d}}$ double in value and the t-statistic from equation (7) does not change.

Similarly, when $\mathrm{k}=-1(\mathrm{k}=-2), \overline{\mathrm{d}}$ (doubles and) changes sign, $\sigma_{\mathrm{d}}$ is the same (doubles in) value and the $\mathrm{t}$ statistic from equation (7) changes its sign only.

5. See for example Levich and Thomas (1993). It should also be noted that the Levich and Thomas estimation of transactions costs is based on monthly trading. Our results are based on quarterly transactions which should make the appropriate transactions costs only one third of this amount.

6. If we assume that the market risk premium $\left(\mathrm{R}_{\mathrm{mt}}-\mathrm{R}_{\mathrm{t}}\right) *$ is the same and positive for both domestic and international CAPMs, then the expected portfolio excess return $\left(\mathrm{R}_{\mathrm{Pt}}-\mathrm{R}_{\mathrm{t}}\right)$ * will assign a higher (lower) $\alpha_{\mathrm{P}}$ when $\beta_{\mathrm{P}}$ is lower (higher).

\section{REFERENCES}

1. Balvers, R., Y. Wu, and E. Gilliland, "Mean Reversion Across National Stock Markets and Parametric Contrarian Investment Strategies," Journal of Finance, Vol. 55 (April), pp. 745-772, 2000.

2. Bilson, J., "The Speculative Efficiency Hypothesis," Journal of Business, Vol. 54, (July), pp. 435-451, 1981.

3. Cheung, Y.W., Wong, C.Y.P., "The Performance of Trading Rules on Four Asian Currency Exchange Rates," Multinational Finance Journal, Vol. 1, pp. 1-22, 1997. 
4. Diebold, F.X., J. Gardeazabal, and K. Yilmaz, "On Cointegration and Exchange Rate Dynamics," Journal of Finance, Vol. 49 (June), pp. 727-735, 1994.

5. Eaker, M. and D. Grant, "Currency Hedging Strategies for Internationally Diversified Equity Portfolios," Journal of Portfolio Management, Vol. 17, pp. 30-32, 1990.

6. Eun, C.S. and B.G. Resnick, "Exchange Rate Uncertainty, Forward Contracts, and International Portfolio Selection," Journal of Finance, Vol. 43 (March), pp. 197-215, 1988.

7. Eun, C.S. and B.G. Resnick, "International Diversification of Investment Portfolios: US and Japanese Perspectives," Management Science, Vol. 40 (January), pp. 140-161, 1994.

8. Eun, C.S. and B.G. Resnick, "International Equity Investment with Selective Hedging Strategies," Journal of International Financial Markets, Institutions, and Money, Vol. 7 (April), pp. 21-42, 1997.

9. $\quad$ Fama, Eugene F., "Forward and Spot Exchange Rates," Journal of Economics, Vol. 36, pp. 697-703, 1984.

10. Fletcher, J., "An Examination of Predictable Risk and Return in UK Stock Returns," Journal of Economics and Business, Vol. 53 (November/December), pp. 527-546, 2001.

11. Frankel, Jeffrey A. and Kenneth A. Froot, "Using Survey Data to Test Standard Propositions on Exchange Rate Expectations," Economic Review, Vol. 77, pp. 133-153, 1987.

12. Froot, Kenneth A., and Jeffrey A. Frankel, "Forward Discount Bias: Is it an Exchange Risk Premium?" Quarterly Journal of Economics, Vol. 416, pp. 136-161, 1989.

13. Froot, K.A. and R.A. Thaler, "Anomalies: Foreign Exchange," Journal of Economic Perspectives, Vol. 4 (Summer), pp. 179-192, 1990.

14. Grinold, R. C. and R.A. Meese, "Strategic Asset Allocation and International Investing," Journal of Portfolio Management, Vol. 27, (Fall), pp. 53-60, 2000.

15. LeBaron, B., "Technical Trading Rule Profitability and Foreign Exchange Intervention," Journal of International Economics, Vol. 49, pp. 125-143, 1999.

16. Lee, C.I., I. Mathur, "Trading Rule Profits in European Spot Cross Rates," Journal of Banking and Finance, Vol. 20, pp. 949-962, 1996.

17. Lee, C.I., M.S. Pan, Y.A. Liu, "On Market Efficiency of Asian Foreign Exchange Rates: Evidence from a Joint Variance Ratio Test and Technical Trading Rules," Journal of International Financial Markets, Institutions \& Money, Vol. 11, pp. 199-214, 2001.

18. Levich, R.M., L. R. Thomas, "The Significance of Technical Trading-Rule Profits in the Foreign Exchange Market: A bootstrap approach," Journal of International Money and Finance, Vol. 12, pp. 451-474, 1993.

19. Madura, J. International Financial Management, $6^{\text {th }}$ edition. Southwestern College Publishing, Cincinnati, Ohio, 2000.

20. Mark, N.C., "Time-Varying Betas and Risk Premia in the Pricing of Forward Foreign Exchange Contracts," Journal of Financial Economics, Vol. 22, (December), pp. 335-354, 1988.

21. Neely, C.J., "Technical Analysis in the Foreign Exchange Market: A Layman's Guide," Review-Federal Reserve Bank of St. Louis, pp. 1-15, 1997.

22. Sinquefield, R.A., "Where are the Gains from International Diversification?" Financial Analysts Journal, Vol. 52 (January/February), pp. 8-14, 1996.

23. Surajaras, P. and R. Sweeney, Profit Making Speculation in Foreign Exchange Markets. Westview Press, Boulder, CO, 1992.

24. Taylor, M.P., "The Economics of Exchange Rates," Journal of Economic Literature, Vol. 33 (March), pp. $13-47,1995$. 


\section{APPENDIX}

\section{General Formulas}

Let $\mathrm{N}$ be the foreign currency principal to be invested in the same currency stock index. For the sake of illustration, consider investing in the German stock market. Then the dollar value of this investment is

$$
\mathrm{W}_{0}=\mathrm{N} * \mathrm{~S}_{0}
$$

where $\mathrm{S}_{0}\left(\mathrm{~S}_{1}\right)=$ current (future) spot rate of DM, in $\$ / \mathrm{DM}$. At the end of the period the dollar value of the investment in the German stock market will be

$$
\mathrm{W}_{1}^{\mathrm{Stk}}=\mathrm{N} *\left(1+\mathrm{R}_{\mathrm{s}}^{\mathrm{DM}}\right) \mathrm{S}_{1}
$$

where $\mathrm{R}_{\mathrm{S}}^{\mathrm{DM}}$ = the rate of return in DMs on the German stock index. If the investor considers a long (short) forward DM contract whose notional principal is $\mathrm{kN}(-\mathrm{kN})$, at maturity that coincides with that of the equity investment, the value of the forward contract will be

$$
\mathrm{W}_{1}^{\mathrm{Fwd}}= \pm \mathrm{kN}\left(\mathrm{S}_{1}-\mathrm{F}_{0}\right)
$$

where $\quad \mathrm{F}_{0}=$ the current forward exchange rate in $\$ / \mathrm{DM}$

$\mathrm{k}=\mathrm{a}$ multiplier that represents the number of times the notional value of the forward contract is higher than the principal of the FX amount invested in the foreign stock index, and +(-) denotes a long (short) forward DM contract.

[Please note that all derived return formulas express actual and expected dollar proceeds on a unitary basis. In practice foreign exchange forward contract units are expressed in multiples of millions of dollars-equivalent.]

At maturity, the value of the foreign equity investment with the forward contract will be

$$
\mathrm{W}_{1}^{\$}=\mathrm{W}_{1}^{\mathrm{Stk}}+\mathrm{W}_{1}^{\mathrm{Fwd}}=\mathrm{N}\left(1+\mathrm{R}_{\mathrm{S}}^{\mathrm{DM}}\right) \mathrm{S}_{1} \pm \mathrm{kN}\left(\mathrm{S}_{1}-\mathrm{F}_{0}\right)
$$

and the dollar return from the above investment will be

$$
\begin{aligned}
\frac{\mathrm{W}_{1}^{\$}}{\mathrm{~W}_{0}^{\$}} & =1+\mathrm{R}_{\mathrm{P}}^{\$}=\frac{\mathrm{N}\left(1+\mathrm{R}_{\mathrm{S}}^{\mathrm{DM}}\right) \mathrm{S}_{1} \pm \mathrm{kN}\left(\mathrm{S}_{1}-\mathrm{F}_{0}\right)}{\mathrm{NS}_{0}} \\
& =\left(1+\mathrm{R}_{\mathrm{S}}^{\mathrm{DM}}\right) \frac{\mathrm{S}_{1}}{\mathrm{~S}_{0}} \pm \mathrm{k}\left(\frac{\mathrm{S}_{1}-\mathrm{F}_{0}}{\mathrm{~S}_{0}}\right)
\end{aligned}
$$

where $\mathrm{R}_{\mathrm{P}}^{\$}$ = portfolio rate of return from the U.S. investor's viewpoint. We assume that the equity component of the portfolio return is independent of its forward component. In other words, we assume that the return performance of the foreign equity index is independent of whether the associated forward contract is long or short. 

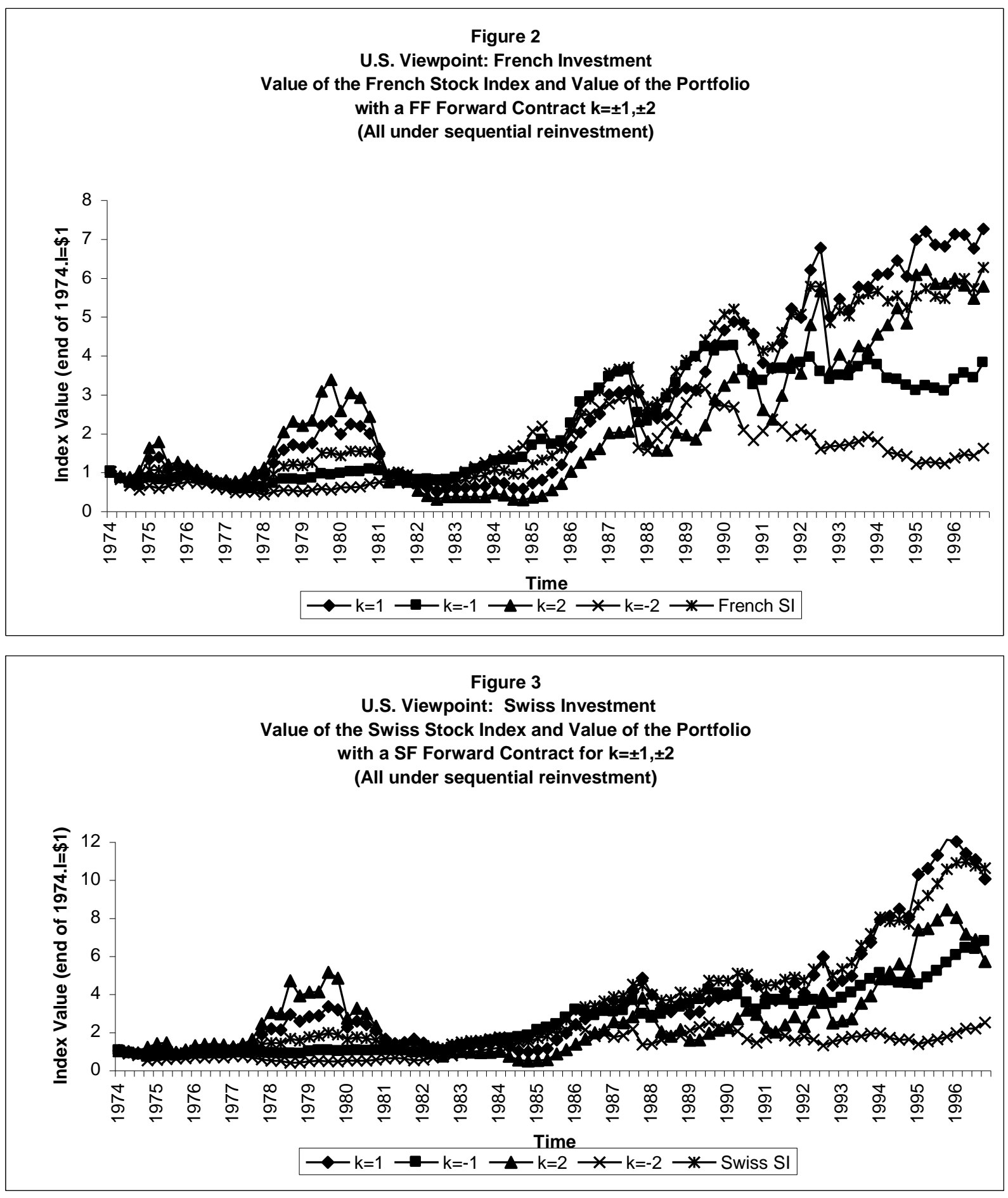

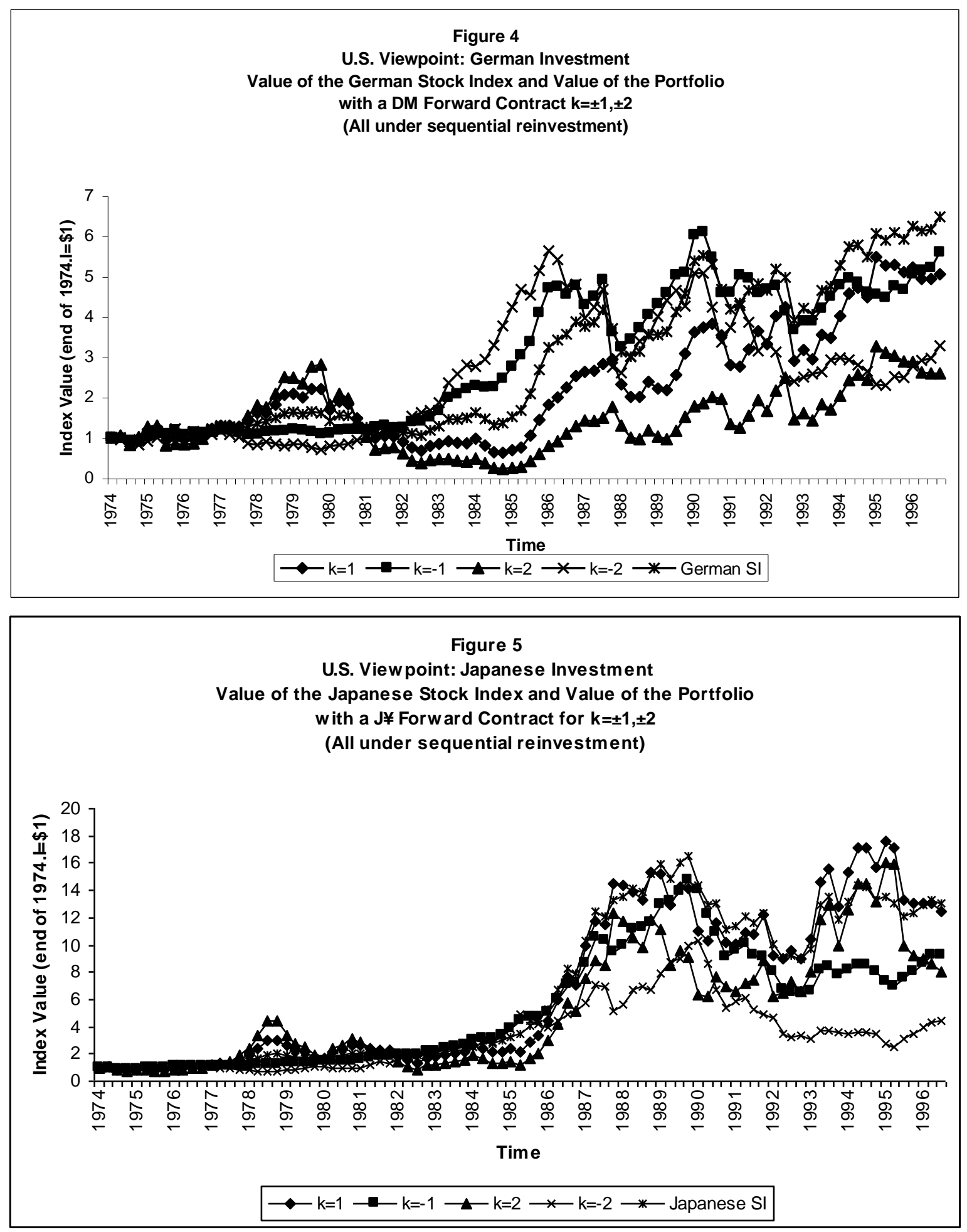


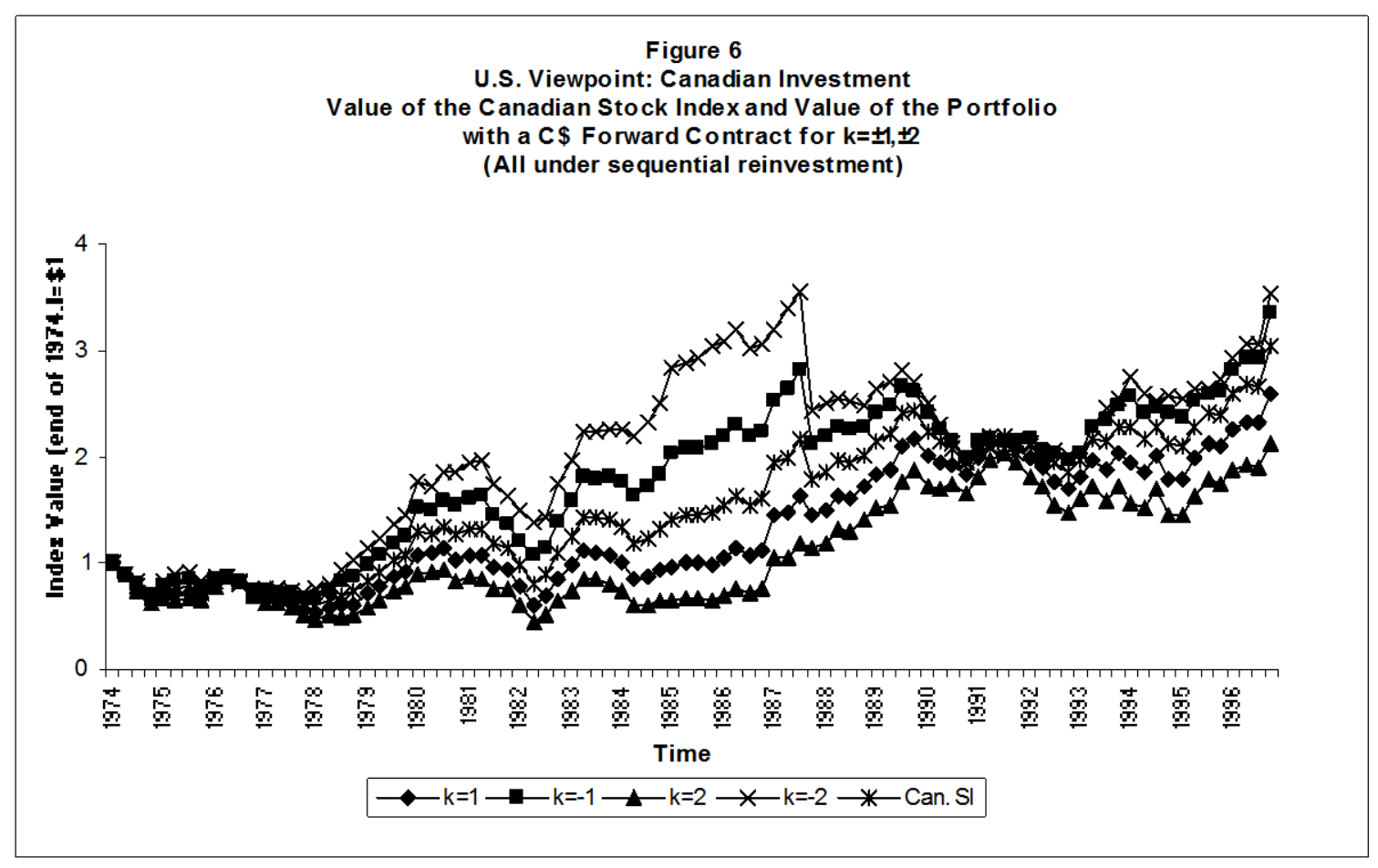

